Original Research Paper

\title{
A Self-Concept Participatory Learning Model for the Improvement of Literacy Skills of the Learners in Community Learning Centres
}

\author{
${ }^{1}$ Mumun Munawaroh, ${ }^{2}$ Dasim Budimansyah, ${ }^{3}$ Enceng Mulyana and ${ }^{3}$ Ace Suryadi \\ ${ }^{I}$ A Postgraduate Student at the School of Postgraduate Studies, \\ Universitas Pendidikan Indonesia, Lecturer of Syekh Nurjati State Islamic Institute of Cirebon, Indonesia \\ ${ }^{2}$ Department of Civic Education, Faculty of Social Sciences Education, \\ Universitas Pendidikan Indonesia, Jl. Dr. Setiabudhi No.229 Bandung, Indonesia \\ ${ }^{3}$ Department of Nonformal and Continuing Education, Faculty of Education, \\ Universitas Pendidikan Indonesia, Jl. Dr. Setiabudhi No.229 Bandung, Indonesia
}

Article history

Received: 15-06-2016

Revised: 23-12-2016

Accepted: 19-01-2017

Corresponding Author:

Mumun Munawaroh

A Postgraduate Student at the

School of Postgraduate Studies,

Universitas Pendidikan

Indonesia, Lecturer of Syekh

Nurjati State Islamic Institute of

Cirebon, Indonesia

Email: mumunroh20@gmail.com

\begin{abstract}
Illiteracy eradication manifests as an important and a common aspect in many countries' development agendas as well as in the United Nation's development initiatives. Indonesia is one of such countries. Based on the data of 2004, Indonesia has at least 28 regencies that still have high illiteracy rates. This condition hinders national growth and development of a country. With a Functional Literacy (FL) program designed and implemented to alleviate illiteracy in the country, this study investigates the effectiveness of a self-concept based participative learning model in improving literacy. The investigation is carried out in Cirebon Regency, on 40 Sub-districts and 125 Community Learning Centers (CLCs). Based on cluster sampling technique, two sub-districts are chosen as the sample for the study. A participative learning model is implemented in this study and an investigation is performed using a quantitative approach, complemented with a qualitative approach. The data is analyzed using three techniques: Descriptive statistical analysis, descriptive qualitative analysis and comparison analysis. Data validity, reliability and objectivity are tested to ensure that the research instruments used are appropriate. From the data analysis, it is concluded that the implemented model is effective in improving learners' literacy skills and it is proven by the difference in literacy skills of the experimental group and the control group. The improvement is also found to be statistically significant, as evidenced by a $t_{\text {calc }}$ value higher than the $t_{\text {table }}$.
\end{abstract}

Keywords: Participatory Learning, Self-Concept, Literacy

\section{Introduction}

Reading and writing skills are among the important skills needed to live in this age. To keep up with this rapidly developing world, reading and writing skills are an absolute necessity as most information is available, presented and conveyed in written form.

An illiterate individual will always lag behind in coping with even some basic advancement in the world. Slamet (2006) also emphasizes the importance of literacy, by stating that it is important for acquiring knowledge and for personal.

For Muslims, the importance of reading was the first instruction that was given to the Prophet Muhammad. The first verse of Al-Quran revealed to the Prophet Muhammad states "Read, in the name of your God who has created (things)." The first thing that Allah commands to Muslims in this first verse is to read. Hence, reading skill (literacy) is a fundamental and important capital for mankind. The fourth verse of the same Surah contains the Arabic word 'qalam', which means 'pen', indicating the importance of written knowledge. These verses indicate that Islam puts high importance in literacy; the holy book of Islam is even called Al-Quran, which means 'something to read'. It seems that the necessity of reading and writing, as stated in the first verse revealed to the Prophet Muhammad, is the main pillar in the creation and development of a civilization.

Despite Indonesia being the world's most populous Islamic nation, illiteracy still abounds in some areas especially among women. A study by Kusmiadi (2013) 
found that literacy education, particularly for women, is a problem yet to be handled. This is because (a) women are uninterested in literacy education, although they have access to it; (b) women access of literacy education is smaller than the men, although the program has been adjusted to women's needs; and (c) culturally, women's movement is limited in terms of getting education.

Women are among the marginalized partly because of Illiteracy and limited access to education. Literacy can empower women and it is the most important means to develop women socially, politically and economically, as argued in the following statement: "Women's issues are global and universal. Illiteracy and limited access to education keep women marginalized. Literacy empowers and it is the most important means through which women can be developed socially, politically and economically" (Oyitso and Olomukoro, 2012, p. 66).

The data in 2012, according to http://www.paudni.kemdikbud.go.id/wpcontent/uploads/2013/07/Buku-Juknis-KeaksaraanDasar-ok.pdf, downloaded on Wednesday, 8 January 2014 , indicates that the percentage of illiterate people of 15 - 59 years old is $4.21 \%$, amounting to 6.401 .522 people. This number of illiterate people has decreased from the previous year. In 2011, there are 6.730 .682 Indonesian of 15 - 59 years of age who are illiterate; consisted of 2.26 .399 men and 4.465.283 women (http://www.paudni.kemdikbud.go.id/wpcontent/uploads/2013/07/Buku-Juknis-Keaksaraan-

Dasar-ok.pdf; downloaded on Sunday, 29 September 2013). In other words, $33.65 \%$ of the illiterates in 2011 are male and $66.34 \%$ of them are female. The higher percentage of female illiterates is due to the fact that there are many women who have no access to education or who drop out of school because of poverty.

To face the challenges of the rapidly changing world, women need to be empowered so that they may have similar rights in various aspects of life, especially in education. Therefore, various attempts to eradicate illiteracy of women are urgently needed.

The efforts to empower women to have equality in education is in line with the global Education for All movement, initiated by UNESCO to meet the educational needs of all children, adolescents and adults by 2015 . The initiative was first formulated in Jomtien, Thailand in 1990, in the World Conference on Education for All.

In the conference, an international community consisted of 155 nations and representatives of around 150 organizations had a consensus to formulate a movement of "universality of basic education and to alleviate illiteracy by the end of the decade." The conference gave birth to the "World Declaration of Education for All" that emphasizes that education is one of the human rights and encourages all nations to strengthen their efforts in improving education to ensure that the "Basic Education for All" needs are satisfied.

The 2014 data on illiteracy in Indonesian regencies shows that there are about 28 regencies with male and female illiterates. The regencies with the highest rate of illiteracy in West Java Province are, in order, Indramayu Regency, Bogor Regency, Cirebon Regency, Karawang Regency and Bekasi Regency. Cirebon Regency is the third regency in West Java with the highest rate of illiteracy; and the eleventh in Indonesia. This fact is confirmed by the Head of Non-formal and Informal Early Age Education Division (PAUDNI) of Cirebon Regency's Office of Education in an article in Fajar Cirebon newspaper on 7 January 2015, page 11 .

The local and national government is trying to solve the problem of women illiteracy by implementing Functional Literacy (FL) Program. The program is based on the Presidential Decree No. 5/2006 on National Movement of Illiteracy Alleviation Acceleration. This decree, issued on 9 June 2006, reinforces the national movement of 9 years compulsory education stated in the Presidential Decree No. 1/1994 on Basic Compulsory Education Implementation.

The implementation of Illiteracy Alleviation Program is also in line with the Literacy Initiative for Empowerment (LIFE) initiated by UNESCO to realize the goals and objectives of United Nation Literacy Decade (UNLD). The focus of Illiteracy Alleviation Program (IAP) includes Basic Literacy, Family Literacy, Entrepreneurial Literacy, Women Empowerment Education, Gender-Based Family Education and Reading Habit Development.

Particular to the effort of eradicating women illiteracy, the Women Illiteracy Alleviation (WIA) program is implemented. It is a national movement to solve the problem of women's lack of education. The WIA program is implemented by the national, provincial, regency/city, sub-districts and district governments. In the provincial level, the WIA is implemented by the Office of Education of the province.

In Cirebon Regency, the program has been implemented since 2004, two years before the Presidential Decree No. 5/2006 on National Movement of Illiteracy Alleviation Acceleration was issued (Mr. Hery, alias, 57 years old, Head of PNFI of Cirebon Regency).

The education process to be literate is not easy, particularly for adults; and even more so for female adults. The implemented method should be persuasive and participative, involving the learners' immediate environment. Compared with other nations in the world, Indonesia is left behind in terms of information gathering through reading (Wahyudin, 2012).

Based on this background, the researcher conducts a study entitled "The Development of Self-Concept Based Participative Learning Model for Literacy Improvement (a Study on Women Empowerment Post Functional Literacy Implementation in Logika Community Learning Center in Cempaka Village, Talun Sub-district, Cirebon Regency).

\section{Objectives}

The final objective of the present study is the formulation of self-concept based participative learning 
model to improve learners' literacy skills after the implementation of Functional Literacy in Cirebon Regency. Specific objectives of the study are:

- To get an overview of the profile of Functional Literacy program graduates in Cirebon Regency

- To get an overview of the implementation of selfconcept based participative learning model to improve learners' literacy skills after the implementation of Functional Literacy in Cirebon Regency

- To find out the extent to which the self-concept based participative learning model is effective in improving Functional Literacy learners' literacy skills in Cirebon Regency

\section{Significances}

Theoretical Significance: -theoretically, the present study is beneficial for:

- The development of General Education (Value Education) discipline, particularly from the positive values of self-concept as the basis of the participative learning to improve literacy skills

- Further researches

Practical Significance: -in practical level, the result of this study is beneficial for the following parties:

- The policy makers in Regional Government, Office of Education and other community institutions that need it

- The female learners of Functional Literacy in the effort to empower themselves so that their existence is acknowledged as one of the human resource assets in national development

- The facilitators and tutors of Functional Literacy program to know the suitable learning program to be implemented, particularly for women; both during the implementation of the FL program and when the program is finished

- The researchers and readers of this paper as positive input and useful information to be implemented in their own fields

\section{Materials and Methods}

The overall study as well as the investigation on model effectiveness is carried out using qualitative approach.

The research procedure is implemented following the steps of Research and Development (R\&D) method as follows: (1) performing preliminary study, theoretical and empirical review is carried out in this stage; (2) formulating the model design to be tested in the field; (3) validating the model design to expert judgment and practitioners; (4) testing the model in the field, which will result in a field-tested model product; (5) conducting final revision of the model; and (6) conducting dissemination and distribution of the result to the public, both through publication and other diffusion methods. Data is collected using interviews, participative observation, non-participative observation, documentation, tests and questionnaires.

The data is analyzed using three techniques; statistical descriptive analysis, qualitative descriptive analysis and comparison analysis. Data validity, reliability and objectivity are tested to ensure that the instruments are appropriate.

The initial product of the research and development is the self-concept based participative learning model. The preliminary model consists of six main components: Rationalization, objectives, scope, steps, developed product and criteria of success. The participants/actors in the present study consist of two groups, the learners and the tutors from each Community Learning Center (4 people). The population of the study is all Community Learning Centers in Cirebon Regency, distributed in 40 sub-districts, amounting to 125 Community Learning Centers. The sample is selected using cluster sampling technique; resulting in the regional sample of two subdistricts, Talun Sub-district and Tengahtani Sub-district. Data is collected through interviews, participative observation, non-participative observation, documentation, tests and questionnaires.

The research instruments consist of three types, according to their functions; i.e., to measure the selfconcept based participative learning needs, to measure the development of participative model and to measure learners' literacy skills. To measure the self-concept based participative learning needs, interview guide, observation guide and questionnaires; formulated by the researcher, are used. To measure the development of participative learning model, the open and unstructured interview guides, formulated by the researcher, are used. Meanwhile, to measure learners' literacy skills, a literacy test formulated by the researcher is used. The data is analyzed using three techniques; statistical descriptive analysis, qualitative descriptive analysis and comparison analysis. Data validity, reliability and objectivity are tested to ensure that the instruments are suitable.

\section{Findings}

Based on the findings and analysis, it is found that there is an increase in literacy skills of the experimental group. The control group also experiences an increase in literacy skills. However, the rate of the increase is higher in the experimental group. Thus, the self-concept based participative learning model implemented in the study is considered effective.

Based on the data analysis, the literacy skills comparison between the experimental and the control groups yields the following: The mean (average) scores of reading, writing and numerical competencies of the 
experimental group are $77.40,76.10$ and 85.33, respectively; while the mean scores of reading, writing and numerical competencies of the control group are $66.53,66.10$ and 76.67, respectively. Therefore, the literacy competence of the experimental group (Logika Community Learning Center) is higher than that of the control group (Lestari Community Learning Center). It can be concluded that the self-concept based participative learning process administered to the experimental group (Logika Community Learning Center) is effective.

All learners who participated in the learning process are female. There is no male illiterate willing to participate in the program due to several reasons such as being embarrassed, considering that learning is not important and being uncomfortable because most of the learners are women.

Based on the data in Fig. 1, the overall self-concept values of the women (learners), in both the experimental and the control groups, are positive. However, the experimental group shows a relatively higher self-concept than the control group. Out of the five indicators measured in the questionnaires, most of the respondents in both groups chose the option 'yes'. The questionnaire is formulated using Guttman scale, as cited by Riduwan (2008: 16).

\section{Reading, Writing and Numeracy Skills of the Learners}

After the treatment of participative learning based on self-concept in the experimental group, the learners' reading, writing and numeracy skills are compared with those of the control group; the result of which is displayed in the following Table 1.

From the table, the average gain score of reading in experimental group is 16.63 , with minimum and maximum gains of 10 and 25 , respectively. In the control group, the average gain score of reading is 4.33 , with minimum and maximum gains of 0 and 10 , respectively. The average gain of writing in experimental group is 14.53 , with minimum gain of 8 and maximum gain of 22; while in the control group, the average gain of writing is 4.33 , with minimum gain of 0 and maximum gain of 10 . Meanwhile, the numeracy average gain of the experimental group is 6.4, with minimum and maximum gains of 0 and 21, respectively. In the control group, the numeracy average gain is 1.5 , with minimum gain of -5 and maximum gain of 20 . Therefore, it is concluded that the reading, writing and numeracy scores of the experimental group are higher than those of the control group.

\section{Contributions Model for the Dignity of Women}

Considering the satisfying results of the model effectiveness tests, as evidenced by the increase in women's reading, writing and numeracy skills (functional literacy skills), the researcher recommends the use of this model in learning process. The self-concept-based participative learning model if proven effective to facilitate women to regard themselves as worthy citizens.

\section{Comparison of the experimental and control groups}

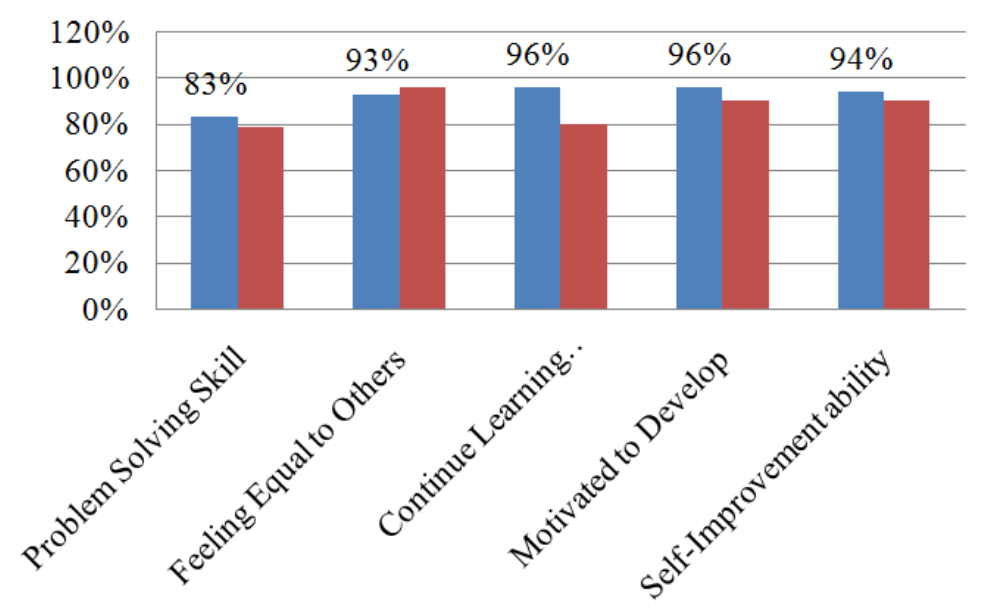

- Experimental(PKBM Cempaka) - Control(PKBM Lestari)

Table 1. Gain score of reading, writing and numeracy skills of the experimental and control groups

\begin{tabular}{lllllll}
\hline Skills & Group & $\mathrm{N}$ & Average gain & Standard deviation & Minimum gain & Maximum gain \\
\hline Reading & Experimental & 30 & 16.63 & 4.39 & 10 & 25 \\
& Control & 30 & 4.33 & 2.71 & 0 & 10 \\
Writing & Experimental & 30 & 14.53 & 3.76 & 8 & 22 \\
& Control & 30 & 4.33 & 2.71 & 0 & 10 \\
Numeracy & Experimental & 30 & 6.4 & 6.14 & 0 & 21 \\
& Control & 30 & 1.5 & 5.28 & -5 & 20 \\
\hline
\end{tabular}


Learners, whose needs of approval are satisfied, will be confident and independent individuals. They will be ready to keep developing themselves. The learners, who often said" what's the use of learning? I am old," during the course of the first field testing of the model, gradually changed their perspective and opinion in the next field tests. They began to understand the importance of learning and became aware of their positions as the primary educator in the family (al-ummu madrosatun aulâ).

In the second field test, a few women had been confident enough to suggest an addition of learning materials, such as fiqh or Al-Qur'an literacy. This occurence indicated that the female learners, who was a group of silent majority in the beginning, began to actively participated in planning, implementing and evaluating their learning process.

The implementation of the model succeeded to make the women regard and portray themselves as individuals who have skills, value, worth and competency. They tend to accept that they are worthy and responsible for their own life. Furthermore, the women participating in the self-concept-based participative learning could represent themselves as citizens equal to the men, with the same opportunities to build a great nation.

Self-esteem, according to Lickona (1991: 53), is closely related with self-concept, both complete each other. For Lickona, self-esteem is useful to shape one's moral feeling, together with other moral feelings; i.e., conscience, empathy, loving the good, self-control and humility. These moral feelings will, in turn, shape one's good character. However, good character formed by moral feelings alone is not enough. It needs two more components, i.e., moral knowing and moral action.

\section{Discussion}

The self-concept based participative learning model is implemented using learning syntax that involves the learners in the planning, implementation and evaluation of the learning process. The learning process is implemented in six stages; (1) building close relationship; (2) identifying learning needs, resources and possible obstacles; (3) formulating learning objectives; (4) formulating learning activities; (5) implementation of learning activities; and (6) evaluation of learning process, result and effects.

The model implemented in the study yields a learning method that can improve learners' literacy skills. Based on the data analysis, the model is effective to improve learners' literacy competencies. This is proven by the difference in literacy competencies of the experimental group and of the control group. The difference is proven to be statistically significant, indicated by the higher value of $t$-calculation $\left(t_{\text {calc }}\right)$ compared with the value of $t$-table $\left(t_{\mathrm{tab}}\right)$.

Concerning the relationship of the learners and the tutors, an equal relationship is built. This is in line with the concept of participative learning that tries to get rid of the subject-object position and to promote the subjectsubject position between the facilitators and the learners. The close relationship between the learners and the tutors is also evidenced in the participative involvement of the learners in planning, implementing and evaluating their learning process.

\section{Discussion}

The participative learning model is formulated by incorporating the variables of self-concept's positive values suggested by Rakhmat (1996); including the values of self-confidence to solve problems, the values of equality in education, the values of sustainable and continuous learning, the values of motivation to improve and the values of self-improvement ability.

The effort to position the learners as active subjects in learning process in the Community Learning Centers is in line with the andragogy learning concept developed by Knowles (1980, p. 38). Andragogy is a technique to involve adult learners in the learning activities, although it can be implemented as a continuum in the practice; from pedagogical approach to andragogy, or vice versa (Sudjana, 2010, p. 6), using the active learning strategy and technique from Silberman (2009).

Based on the analysis and hypothesis testing, it can be concluded that the self-concept based participative learning model developed in the present study is effective to improve learners' literacy competencies (reading, writing and numerical skills) post functional literacy implementation.

The improvement in reading, writing and numerical competencies of the experimental group is caused by, in part, the fact that the women participating in the learning process at Logika Community Learning Center are highly motivated to learn and are supported by their significant others; including the husbands, children, families, tutors and literacy education organizers, to possess positive self-concept.

During several times of model testing in the experimental group, it is clearly apparent that the tutors facilitate the learners to value their own potentials. The value of self-concept is illustrated as the value assigned by other individuals/group of individuals to a person based on how positive, or how negative, the person values him/herself.

Self-concept is not inherent to any individual; there is no baby ever born with inherent self-concept. Since it is not a given status, self-concept can be taught or socialized in, at least, four primary agents of socialization: In the family, among peers, in the school and in social media. In addition to the socialization in the primary agents, self-concept can also be developed in secondary agents of socialization; i.e., in religious institutions, neighborhood, recreational organizations, general public and in professional or work environments. 
One of the agents who socialize the positive values of self-concept is the tutor of functional literacy program; who has learned self-concept based participative learning model in discussion with the researcher.

Self-concept is dynamic. It consistently changes in accordance to the amount of interaction an individual experiences. Although changes may occur from positive to negative condition and vice versa, the changes expected in the FL program is the changes from negative self-concept to a positive self-concept. One of the psychological theorists who experience this kind of changes is Abraham Harold Maslow. In his childhood age, Maslow was a shy, not confident and depressed child. However, he changed into a courageous adolescent and became a brilliant student due to a lot of interactions with the people in his surroundings.

Maslow, along with Rogers, is the representative of the humanitarian psychology discipline that views human personality from a more positive, brighter, healthier and more optimistic side; compared with the previous disciplines of psychology (the behaviorism and psychoanalysis). Humanitarian psychology is also in line with the opinion of Paulo Freire, a humanitarian educator. It is important to regard human personality from the more positive, brighter, healthier and more optimistic side so that individuals can achieve satisfaction in life; which is the objective of general education.

The success of female learners in improving their reading, writing and numerical competencies in Functional Literacy is reflected in their interaction with the tutors. Mead, cited in Johnson (Lawang, 2005) believe that self-concept is a process resulting from social interaction of individuals with others.

The findings from questionnaires, administered to find out the self-concept of female learners in both the experimental group (learners in Logika Community Learning Center) and the control group (learners in Lestari Community Learning Center); indicate that the learners' self-concepts tend to be positive.

The indicators of self-concept in the questionnaires are adapted and adjusted by the researcher to suit the condition of the female learners; formulated into several items.

\section{Conclusion}

Since the introduction of Convention on the Elimination of All Forms of Discrimination against Women (CEDAW) by the UN in 1980, various efforts have been performed to eradicate all kinds of discriminations against women, including in the field of education. The efforts to empower women so that they can get equality in education are congruent with the global movement of Education for All led by UNESCO. One of the programs is literacy training for adult women. Adult learning should be reinforced so that the women can achieve improvement in their literacy skills. Through self-concept-based participative learning model, the affective domain of the women is developed to complete the improvements in their cognitive and psychomotor domain. This is in line with the national objectives of General Education; which is to comprehensively focus on all aspects of a person and to educate the people comprehensively through the development of their cognitive, affective and psychomotor.

This model is implemented in literacy learning at the Logika Desa Cempaka Community Learning Center, Talun Sub-district, Cirebon Regency. The result of the implementation indicates that the self-concept of the women participating in the learning process in experimental class is relatively better than that in the control class. The women's reading, writing and numeracy skills also improve more significantly in experimental class, compared with those in the control class.

\section{Acknowledgement}

We wish to thank the Rector IAIN Syeikh Nurjati Ceribon for the support offered during the process of writing this paper which is based on the writers' previous research together with the promotors at Universitas Pendidikan Indonesia who worked tirelessly and made sure this paper is finalized.

This research and publication has been funded by the IAIN Syeik Nurjati Ceribon in cooperation with Universitas Pendidikan Indonesia. Upon this, we thank the institutions' top administration for their kind reports.

\section{Author's Contributions}

Mumun Munawaroh: She is the main author of this manuscript. She worked hard to make a final manuscript of the paper.

Dasim Budimansyah: He is the promotor of Mumun, he made sure the first author writes a good dissertation.

Enceng Mulyana: He is the co-promotor, he made sure the work is proof read and written well.

Ace Suryadi: He guided Mumun and also made final proof reading of the manuscript.

\section{Ethics}

We declare that all academic procedures and ethics have been followed in the process of editing this paper and writing this manuscript.

\section{References}

Knowles, M., 1980. The modern practice of adult education: From pedagogy to andragogy. Cambridge Adult Education, Englewoods Cliff, NJ.

Kusmiadi, 2013. Partisipasi Anggota Kelompok Wanita Tani Pada Kegiatan Percepatan Penganekaragaman Konsumsi Pangan (P2KP) Di Kecamatan Talawi, Kota Sawahlunto, Provinsi Sumatera Barat. Jurnal Pertanian. 
Lickona, T., 1991. Educating for Character: How our Schools can Teach Respect and Responsibility. 1st Edn., Bantam, New York, ISBN-10: 0553075705, pp: 478.

Lawang, R.M.Z., 2005. Kapital Sosial: Dalam Perspektif Sosiologik. Fisip UI Press, Jakarta.

Oyitso, M. and C.O. Olomukoro, 2012. Enhancing women's development through literacy education in Nigeria. Canadian Center of Science and Education.

Rakhmat, J., 1996. Psikologi Komunikasi Edisi Revisi. Remaja Rosdakarya, Bandung.

Riduwan, 2008. Skala pengukuran variabel-variabel penelitian. Alfabeta, Bandung.
Silberman, M.L., 2009. Active Learning. Indo Reader Insan Mandiri, Sleman.

Slamet, 2006. dalam Jurnal Pendidikan 12 No. 2 Desember 2006, diperoleh dari.

Sudjana, 2010. Metode dan Teknik Pembelajaran Partisipatif. Falah Production, Bandung.

Wahyudin, 2012. Perancangan dan pembuatan tachometer portable dengan media penyimpanan data multimedia card berbasis mikrokontroler atmega 32. PhD. Thesis, University of Muhammadiyah Malang. 